THE NATURALIST ON THE RIVER AMAZONS 



\title{
HENRY WALTER BATES
}

\author{
THE
}

Naluralist

ON THE

RIVER

\section{AMAZONS}

\author{
FOREWORD BY \\ ROBERT L. USINGER
}

UNIVERSITY OF CALIFORNIA PRESS BERKELEY AND LOS ANGELES: 1962 
University of California Press

Berkeley and Los Angeles, California

Cambridge University Press

London, England

Reprinted from the second edition

John Murray, London, 1864

(First Paper-bound Edition) 